\title{
VIRAL NANOPARTICLE AS A POTENTIAL DRUG CARRIER FOR TARGETED DRUG DELIVARY SYSTEMS
}

\section{S. SARAN ASWATHAMAN}

Student, PSG College of Pharmacy, Coimbatore, Tamil Nadu, India

\begin{abstract}
The modern world is filled with life-threatening diseases and to cure these diseases new drugs are invented and administered. The side effects of these drugs on patient administration are even more life-threatening. These side effects are generally caused because these drugs administered are not targeted specific.

So, the main objective of this project is to create a novel drug delivery system which is highly targets specific and which cures the disease with no side effects.

KEYWORDS: Hibiscus Chlorotic Ringspot Virus, DOXORUBIN \& Breast Cancer
\end{abstract}

Received: Mar 05, 2018; Accepted: Mar 26, 2018; Published: Apr 17, 2018; Paper Id.: IJMPSAPR201811

\section{INTRODUCTION}

Viruses have a highly targeted specific in nature. And these viruses can be used as a carrier for targeted drug delivery systems if its RNA or its genetic material is removed from its protein core. We can use human viruses and plant viruses as carriers. I have chosen plant virus because they are highly targeted specific. Chemical functionalization of a plant viral particle surface can impart stealth properties to prolong in vitro circulation and a good half- life. They are also highly biocompatible.

\section{OBJECTIVE}

The objective of this study is to prepare a DOXORUBIN loaded in HIBISCUS CHLOROTIC RINGSPOT VIRUS protein cage which acts as a drug carrier with folic acid conjugation.

\section{PRINCIPLE}

- Removal of viral RNA from the plant virus and purification of coat protein.

- Encapsulation of poly acids and doxorubicin during reassembly of the protein cage.

- The use of poly acids is to have controlled release.

- Conjugation of folic acid onto the viral coat protein.

- The use of folic acid is because it specifically targets only breast cells. 


\section{METHODOLOGY}

- Virus-like particles was readily produced by destabilizing the HCRSV in $8 \mathrm{M}$ urea or Tris buffer $\mathrm{pH} 8$ in the absence of calcium ions.

- The removal of viral RNA can be done by ultra high-speed centrifugation.

- The loading of drug molecules into the viral-like proteins is dependent on electrostatic interactions.

- Anionic poly acids such polystyrene sulfonic acid and anionic drug molecules are successfully loaded.

- $\quad$ The reassembly of the coat protein is done with sodium acetate buffer $\mathrm{pH} 5$.

- $\quad$ Folic acid can also be conjugated along with it.

\section{RESULTS}

A Virus is highly targeted specific, it only attaches itself to the cancer cells at a particular diseased site. The cancer is cured and the side effects of chemotherapy are minimized to a very large extent.

\section{REFERENCES}

1. https://www.sciencedirect.com/science/article/pii/S0959440X17300428

2. https://f1000research.com/articles/6-1541/v1

3. https://www.ncbi.nlm.nih.gov/pmc/articles/PMC3156490/ 